\title{
Growth promotion of the rice genotypes by pgprs isolated from rice rhizosphere
}

\author{
A. Sharma ${ }^{1}$, D. Shankhdhar ${ }^{1}$, A. Sharma ${ }^{2}$ and S.C. Shankhdhar ${ }^{1 *}$ \\ ${ }^{1}$ Department of Plant Physiology, College of Basic Sciences and Humanities, G. B. Pant University of Agriculture and Technology, \\ Pantnagar-263145. (U. S. Nagar) Uttarakhand. India. ${ }^{2}$ Department of Microbiology, College of Basic Sciences and Humanities, \\ G. B. Pant University of Agriculture and Technology, Pantnagar - 263145. (U. S. Nagar) Uttarakhand. India. "Corresponding \\ author:shankhdhar.sc@rediffmail.com
}

\begin{abstract}
Plant growth promoting rhizobacteria (PGPRs) improve growth of the host plants in a variety of ways. For this reason five bacterial strains isolated form the rice rhizospheric soil (B 15, B 17, B 19, BN 17 and BN 30) and three standard PGPR strains (viz. Pseudomonas putida, Pseudomonas fluorescens and Azospirillum lipoferum) were tested for plant growth promotion when applied to the rice plants as seedling treatments. The experiment was conducted for two rainy seasons of the years 2010 and 2011. Rice plants inoculated with the bacterial isolates recorded an improved plant growth and higher photosynthetic capacity signified by the higher chlorophyll content. Root and shoot dry mass was also found to be increased in the inoculated plants. Besides these iron and zinc content of the treated rice plants was also found to be higher in comparison with the uninoculated control plants. Hence, it can be concluded that application of PGPR has immense potential to be used as agricultural crop inoculants as they promote plant growth as well as improve the health and yield of the plants.
\end{abstract}

Keywords: PGPR, IAA product

\section{Introduction}

Bacteria that colonize the plant roots and surrounding rhizosphere, enhance plant growth by a variety of different mechanisms are referred to as plant growthpromoting rhizobacteria (PGPR). PGPR have been applied to various crops to enhance growth, seed emergence and crop yield, and some have also been commercialized (Herman et al., 2008; Minorsky, 2008). Pseudomonas fluorescens B16 isolated from the roots of graminaceous plants has been shown to colonize the roots of various plants, and to increase the height, flower number, fruit number and total fruit weight of tomato plants (Minorsky, 2008). PGPRs isolated from rice fields were shown to increase plant height, root length, and dry matter production of shoot and root of rice seedlings. The properties of PGPRs like growth enhancement, IAA production and phosphorus solubilization has extended the use of these bacteria as inoculant biofertilizers for many different host plants (Ashrafuzzaman et al., 2009). With rice, Azospirillum brasilense (James et al., 2000), Herbaspirillum seropedicae (Baldani et al., 2000), Burkholderia vietnamensis (Baldani et al., 
2000) and Rhizobium leguminosarum bv. trifolii (Yanni and El-Fattah, 1999) have all been prove to be effective in improving rice growth and showed an increase in rice yield in field studies. Plant growth promoting rhizobacteria exert their effect on plants in a variety of ways i.e. they can act as biofertilizers like Rhizobium and Bradyrhizobium (Van Rijhn and Vanderlayden, 1995); Azospirillum (Okon et al., 1998) and phosphorus solubilizing bacteria (Vassilev et al., 2006). PGPR can also be used as rhizoremediators (Kuiper et al., 2001); phytostimulators (Lugtenberg and Kamilova, 2009) and stress controllers (Glick et al., 2007).

Various reports have been published on the growth promotion by the PGPR strains in a variety of crops. IAA production and $\mathrm{P}$ solubilization resulting in an increase in the root and shoot length, fresh weight, dry weight, nutrient uptake has been reported in lentil (Zafar et al., 2012) and cowpea (Minaxi et al., 2012). However, in case of rice increased root length, shoot length, aerial biomass and increased nutrient uptake has also been reported in response to the PGPR application (Salamone et al., 2012). These changes in the plant morphology and nutrient content result because root associated bacteria change the chemical and physical properties of the soil surrounding the roots of the host plants so as to facilitate the host plant to acquire better nourishment at the expense of minimum input. With these facts in mind an experiment was performed with the following objectives: 1) to evaluate the bacteria associated with rice roots for growth promoting characteristics in field trials conducted over two rainy seasons of 2010 and 2011; and 2) to study the growth promotion and micronutrient uptake by the rice plants to obtain consolidating proofs for the action of plant growth promoting rhizobacteria.

\section{Materials and Methods}

\subsection{Bacteria isolates}

Three standard PGPR strains viz. Pseudomonas putida MTCC 102, Pseudomonas fluorescens MTCC 103 and Azospirillum lipoferum MTCC 2694 were obtained from Microbial Type Culture Collection, Institute of Microbial Technology, Chandigarh, India. Besides these, many bacteria were isolated from rice fields by enrichment culture technique. Soil was collected from the rhizospheric zone of rice plants from different locations in N E Borlaug Crop Research Centre, Pantnagar, from these soils different bacteria were isolated and purified to single species and assayed in vitro for Fe solubilisation on chrome azurol-S agar (CAS) media as described by Schwyn and Neilands (1987) and for zinc solubilization on Bunt and Rovira media with $\mathrm{ZnO}$ as insoluble zinc source (Bunt and Rovira, 1955). Of all the strains, five of the better Fe and $\mathrm{Zn}$ solubilising strains were selected and tested in the field for Fe and $\mathrm{Zn}$ solubilising activity in situ and they were proved to increase Fe/Zn uptake by the plants. Also the sequence analysis and alignment of the 16S rRNA gene of the bacterial isolates show that the isolates belong to the Enterobacter species.

\subsection{Plant material and treatment}

Seeds of three rice genotypes Jaya, PA6444, and Pusa basmati-1, were obtained from the Department of Genetics and Plant Breeding, College of Agriculture, G.B. Pant University of Agriculture and Technology, Pantnagar, India. The seeds were surface sterilized by $1 \%$ sodium hypochlorite solution for $2-3$ min and $90 \%$ ethanol for 3-4 min, then washed with distilled water and sown for nursery raising. The bacterial isolates were grown as liquid cultures in Luria broth. After obtaining sufficient population density of around $10^{6}$ to $10^{7} \mathrm{cfu} /$ $\mathrm{ml}$, they were applied to plants; 21-day old seedlings were uprooted and dipped in the bacterial culture for sufficient time to allow the bacteria to colonize the roots, later analysis showed that roots had a population of almost $10^{5} \mathrm{CFU} / \mathrm{g}$ of fresh roots. Then the seedlings were transplanted in the field in a strip plot design for two kharif seasons 2010 and 2011. The soil of the transplantation site belonged to Typic Happlodoll. It had gentle to moderate slope and was fine, loamy and mixed hyperthermic type. The physico-chemical conditions of the soils include a $\mathrm{pH}$ of 7.4 having an electrical conductivity of $0.266 \mathrm{dS} / \mathrm{m}$ and organic 
carbon content of $10.5 \mathrm{~g} / \mathrm{kg}$ soil. Also the nitrogen content of the soil was $31.8 \mathrm{mg} / \mathrm{kg}$ and phosphorus content was $10.12 \mathrm{mg} / \mathrm{kg}$. DTPA extractable $\mathrm{Zn}$ was $0.47 \mathrm{mg} / \mathrm{kg}$, Fe was $25.3 \mathrm{mg} / \mathrm{kg}, \mathrm{Cu} 1.24 \mathrm{mg} / \mathrm{kg}$ and Mn $5.97 \mathrm{mg} / \mathrm{kg}$. Geographically, the site lies in the tarai plains about $30 \mathrm{~km}$ southwards of foothills of Shivalik range of Himalayas at $29^{\circ} \mathrm{N}$ latitude, $79^{\circ} 29^{\prime} \mathrm{E}$ longitude and at an altitude 243.8 meter above the sea level and experiences humid subtropical climate with hot dry summers and cool winters. Winter season extends from November to March. The monsoon sets during second or third week of June and continues till September end. Fertilizer doses of nitrogen (100 kg/ha), phosphorus $(60 \mathrm{~kg} / \mathrm{ha})$, potassium $(45 \mathrm{~kg} / \mathrm{ha})$ and irrigation were applied as per recommendations.

30 days after transplanting, 3 plants from each plot were selected and the observations like plant height, tiller number, leaf number, root dry matter, shoot dry matter, chlorophyll content, iron and zinc content in roots and shoots were recorded in 3 replications each. Plant height, tiller number and leaf number were measured in the field itself, whereas for root and shoot dry mass three plants from each plot were carefully uprooted. Chlorophyll content of the freshly harvested leaves was measured by the protocol given by Hiscox and Israelstam, 1979. 50 mg finely chopped leaves were dipped in $10 \mathrm{ml}$ DMSO (Dimtehyl Sulfoxide) and kept at $60{ }^{\circ} \mathrm{C}$ for 3 hours. Then OD was recorded at 663 and $645 \mathrm{~nm}$ with a UVVIS spectrophotometer (UV-VIS Spectrophotometer 108; Systronics) and chlorophyll content was calculated by using following formulae:

$$
\left[\left(12.7 \times O D_{663}-2.63 \times O D_{645}\right) \mathrm{X} V\right]
$$

$\operatorname{chl} \mathrm{a}=\quad W g \times 1000$

$$
\left[\left(22.9 \times O D_{645}-4.48 \times O D_{663}\right) \times V\right]
$$

chl $b=$

$$
\text { Wg X } 1000
$$

Where,

Chlorophyll content $=\mathrm{mg} / \mathrm{g}$ fresh weigt. $\mathrm{V}=$ volume of DMSO used. Wt. $=$ Weigth of tissue used in gram
Thereafter, root and shoot portions were washed successively with tap water, $0.1 \mathrm{~mol} / 1 \mathrm{HCl}$ and then distilled water to remove contamination. Then the samples were oven-dried and weighed separately and were also used for the estimation of $\mathrm{Fe}$ and $\mathrm{Zn}$ contents. $1 \mathrm{~g}$ dried samples from different plant parts were taken for $\mathrm{Fe}$ and $\mathrm{Zn}$ estimation by atomic absorption spectroscopy, according to the method described by Pirzadeh et al. (2010).

\subsection{Statistical analysis}

The data of the various parameters was analyzed in triplicates and subjected to ANOVA (Analysis of variance) in accordance with the experimental design (strip plot design) using SPSS-16 statistical package to quantify and evaluate the source of variation. The treatment means were compared at a significance level of 0.05 and the ranking of treatments denoted by alphabets. The treatments denoted by different letters in the each column of tables and figures represent significantly different values among the treatments.

\section{Results}

\subsection{Vegetative plant growth}

Various growth parameters like plant height, number of tillers, number of leaves, root dry matter and shoot dry matter were recorded to study the effect of bacterial application on the growth of inoculated rice plants in comparison to the uninoculated control plants. A significant increase in plant height of the rice plants treated with different bacterial isolates was observed in comparison to the untreated control plants (Table 1). Among different treatments, P. Putida, P. fluorescens, A. lipoferum and B 15 were effective in increasing the plant height in all the genotypes under study in comparison with uninoculated control. Plant height of the treated rice plants was higher for the treatments $P$. fluorescens with an increase of $25.2 \%$ in Jaya and 25\% in PA6444 and A. lipoferum in Pusa basmati-1 with an increase of 
$18.8 \%$ during 2010 in comparison to the control, while during 2011, treatments BN $30 \mathrm{inJ}$ aya (9.8\% increase), B 15 in PA6444 (18.8\% increase) and P. fluorescens in Pusa basmati-1 (16.3\% increase) were most effective in increasing the plant height. However, statistically $P$. putida proved to be most effective in influencing the plant height of the rice plants.

Besides plant height; tiller and leaf number are also important parameters in terms of the vegetative growth of the plants and were also found to be increased in response to bacterial treatments (Table 1). Maximum number of tillers was recorded for the treatments P. fluorescens in Jaya (48\% higher than control), $A$. lipoferum in PA6444 (36.3\% higher) and P. fluorescens in Pusa basmati-1 (29.4\% higher) during 2010; while during 2011, treatment $P$. fluorencens was most effective in increasing the tiller number of treated rice plants with an increment of $24.4 \%$ in Jaya and PA6444 each and $29 \%$ in Pusa basmati-1 in comparison to the control. Similarly leaf number was also found higher for the treatments $P$. fluorescens in Jaya (55.4\% increase), $P$. putida in PA6444 (42.7\% increase) and BN 17 in Pusa basmati-1 (50.2\% increase) during 2010 in comparison to the uninoculated control, and during 2011, treatments B 15 in Jaya (22.5\% increase), BN 30 in PA6444 (27.6\% increase) and P. fluorescens in Pusa basmati-1 (21.3\% increase) proved most effective in increasing the leaf number of the treated plants in comparison with control.

Root and shoot dry matter was also recorded (Table 2) to study the effect of PGPR application on dry matter accumulation by the plants. Root dry matter was found to be higher for all the treatments in all the genotypes when compared with control over both the years. During 2010, the treatments B 15 in Jaya (41.2\% increase), P. fluorescens and B 19 in PA6444 (each with 33.4\% increase) and B 17 in Pusa basmati-1 (36.8\% increase) proved to be most effective in increasing the root dry matter; whereas during 2011, maximum increase in the root dry matter was observed for the treatments B 19 in Jaya (49.7\% increase) and P. putida in PA6444 and Pusa basmati-1 (44.3\% and 31.1\% increase respectively). Similarly, shoot dry matter was also found to be higher for the treated rice plants when compared with the uninoculated control plants during both the years. During 2010, the treatments P. putida through B 19 showed a clear increase in the shoot dry mass in all the genotypes. The treatments B 15 in Jaya $(33.2 \%$ increase), B 19 in PA6444 (28.9\% increase) and B 17 in Pusa basmati-1 (36.8\% increase) were found most effective in increasing the shoot dry mass of the rice plants in comparison with control, while during 2011, highest shoot dry mass was found for the treatments B 19 in Jaya (34.8\% increase), B 17 in PA6444 (43\% increase) and P. fluorescens in Pusa basmati-1 (32.8\% increase) when compared with uninoculated control plants. Upon overall analysis of the data on vegetative growth of the rice plants, the treatments P. putida, P. fluorescens, B 17 and B 19 were found most effective in influencing the vegetative growth of the inoculated rice plants.

\subsection{Chlorophyll content}

Chlorophyll a (Figure 1) and chlorophyll b (Figure 2) content was also estimated to predict plant's health and photosynthetic capacity in response to the bacterial inoculation. Chlorophyll content was found higher for the treated plants in comparison to the uninoculated control plants. The treatment A. lipoferum showed maximum increase in the chlorophyll a as well as chlorophyll $\mathrm{b}$ content in all the three genotypes during both the years. In response to the bacterial treatments, an increase of $52.3 \%$ in Jaya, $58.8 \%$ in PA6444 and 57.4\% in Pusa Basmati-1 was observed in chlorophyll a content and an increase of $58.2 \%$ in Jaya, $60 \%$ in PA6444 was recorded for chlorophyll $\mathrm{b}$ content in response to the treatment by A. lipoferum, however, Pusa basmati-1 showed an increase in chlorophyll $\mathrm{b}$ content in response to the treatment by bacterial isolate $\mathrm{BN} 30$ showing an increase of $64 \%$ during 2010 while, during 2011 an increase of $44.4 \%$ in Jaya, $55 \%$ in PA6444 and 50.9\% in Pusa basmati-1 in chlorophyll a content and $45.8 \%$ in Jaya, $51.9 \%$ in PA6444 and 51.2\% in Pusa basmati-1 in chlorophyll $\mathrm{b}$ content in response to the treatment by $A$. lipoferum was recorded in the treated plants in comparison to the control. 
Table 1. Effect of seedling treatment with different plant growth promoting rhizobacteria on plant height, tiller number, leaf number in three genotypes of rice 30 days after transplanting.

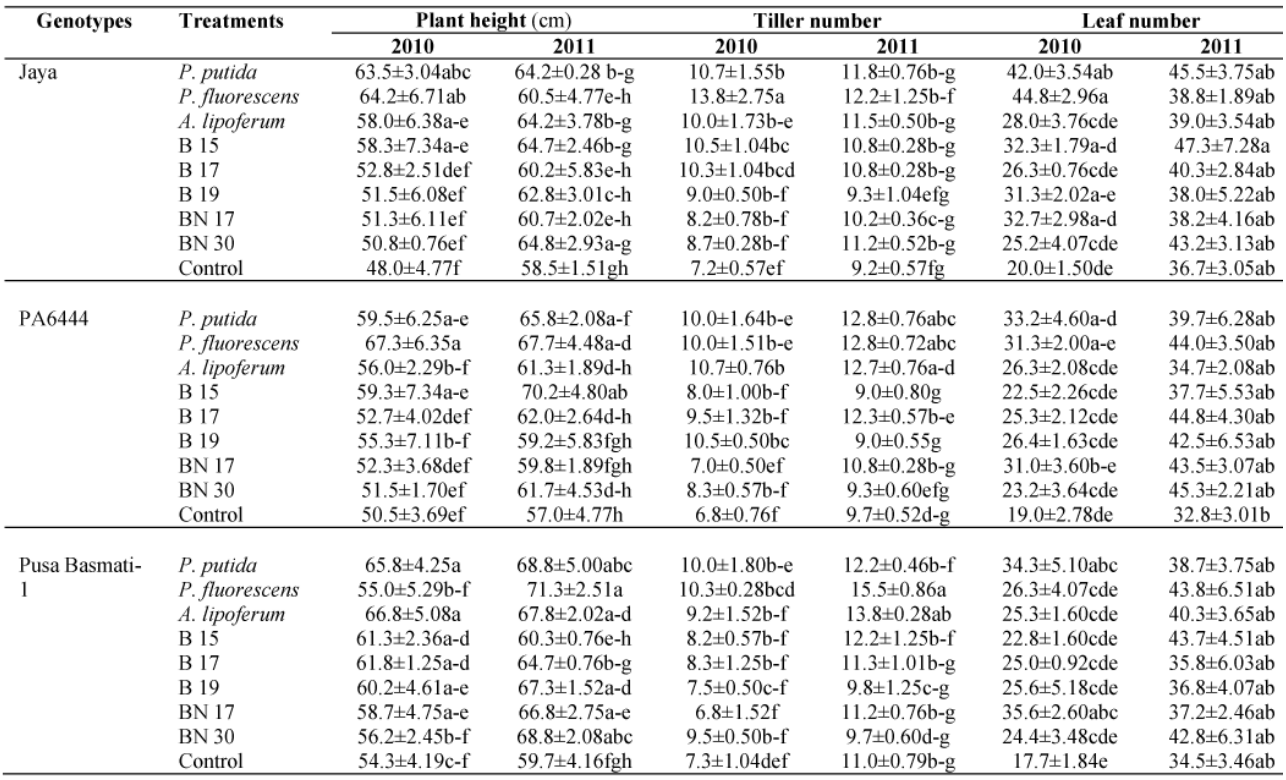

Means followed by a common letter in the columns are not significantly different.

\subsection{Iron and zinc content in plants}

Iron and zinc content in roots and shoots of the treated rice plants was estimated to observe whether PGPR application had any effect on the micronutrient content of the plants. Root Fe content was found to be higher in all the treatments and in all the genotypes (Table 3a, b). During 2010, highest root Fe content was observed for the treatments P. putida in Jaya (36\% higher) and PA6444 (33\% higher) in comparison to the control and $P$. fluorescens in Pusa basmati-1 (33.5\% higher) however, during 2011 the treatments B 17 in Jaya (27.6\% increase), $P$. putida in $(27.6 \%$ increase), $P$. putida in PA6444 (22.6\% increase) and $P$. fluorescens in Pusa basmati-1 (33.3\% increase) proved to be most effective in increasing the root $\mathrm{Fe}$ content in treated plants. Whereas, in case of shoots (Table 3a, b), the treatments B 19 in Jaya (54\% increase), P. fluorescens in PA6444 (53.3\% increase) and Pusa basmati-1
(37\% increase) during 2010 and B 17 in Jaya $(60.3 \%$ (37\% increase) during 2010 and B 17 in Jaya (60.3\% increase), P. fluorescens in PA6444 (49.5\% increase) and P. putida in Pusa basmati-1 (48.9\% increase) during 2011 proved to be most effective in increasing the shoot Fe content of the treated plants when compared with the control plants.

Measurement of the zinc content (Table 3a, b) revealed that the treatments $P$. fluorescens in Jaya $(36.8 \%$ increase), P. putida in PA6444 (36.8\% increase) and BN 30 in Pusa basmati-1 (26.5\% increase) during 2010 and B 15 in Jaya (47.9\% increase), BN 17 in PA6444 (74.4\% increase) and $P$. putida in Pusa basmati-1 (63.6\% increase) during 2011 were most effective in increasing the root $\mathrm{Zn}$ content of the treated rice plants in comparison to the uninoculated control plants. Whereas the treatment B 17 was most effective in increasing the shoot $\mathrm{Zn}$ content of the treated rice plants 
during both the years. An increment of $45.1 \%$ in Jaya, during both the years. An increment of $45.1 \%$ in Jaya, $51.6 \%$ in PA6444 and 37\% in Pusa basmati-1 during 2010 and $62.8 \%$ in Jaya, $60.9 \%$ in PA6444 and $62.2 \%$ in Pusa basmati-1 during 2011 was recorded in shoot $\mathrm{Zn}$ content in the rice plants treated with the isolate B 17 in comparison to the control.

\subsection{Yield attributes}

Harvesting of plants was done after grain maturity during both the years and the data on number of filled grains is presented in Figure 3. Data on grain number showed an enhancing effect of the bacterial treatments in increasing grain number. During 2010 maximum number of grains were reported for the treatments B 19 in Jaya (50.8\% higher than the control), BN 30 in PA6444 (36.7\% higher) and BN 17 in Pusa basmati-1 (43.5\% higher). Whereas, during 2011 treatments B 19 in Jaya (40.3\% increase), B 17 in PA6444 (39.1\% increase) and P. fluorescens in Pusa basmati-1 (42.1\% increase over the control) were most responsive in enhancing the filled grain number. Accordingly, grain yield showed an increase for the isolates $\mathrm{BN} 17$ during 2010 and BN 30 during 2011 in Jaya (23.3\% and $30.4 \%$ respectively), BN 30 during 2010 and B 17 and P. putida during 2011 in PA6444 (29.8\% and 35.2\% respectively) and B 15 during 2010 and P. fluorescens during 2011 in Pusa basmati - 1 (29.6\% and 40.7\% respectively) in comparison to the control (Figure 4).

\section{Discussion}

Vegetative growth phase is most important growth phase of any crop as it decides the amount of biomass generated and particularly in rice, it is important for the development of tillers. A vigorous vegetative crop growth represents a higher plant height, larger number of leaves and tillers and correspondingly higher root and shoot dry mass. In our investigation, plant height, leaf number, tiller number, root dry mass and shoot dry mass were all found to be higher in response to the bacterial inoculation. Similarly a $20 \%$ increase in the plant height of 30 day old rice plants was observed in response to PGPR application (Ashraffuzzaman et al., 2009). Besides plant height, increase in the number of tillers (Kumar et al., 2012; Salamone et al., 2012) and number of leaves (Ashraffuzzaman et $a l ., 2009)$ was also reported in the rice plants treated with the plant growth promoting rhizobacteria. Moreover, root and shoot dry matter was also found to be higher for the treated plants in comparison to the uninoculated control. The increase in the root dry mass directly correlates with the increased plant vigour, plant growth promotion and improvement in the micronutrient status of the plants. In similar experiments an increase in the root dry mass in response to treatment by $P$. putida, $P$. fluorescence and A. lipoferum was reported by Gholami et al. (2009) in maize; besides almost 30\% higher root dry mass in response to bacterial isolates was reported by Souza et al. (2012) in rice; Rana et al. (2012), also reported higher root dry mass in wheat plants in response to PGPR treatment. Also, an increase in the shoot dry matter directly correlates to the plant's productivity. In our investigation, bacterial treatments increased plant vigour, number of leaves and tillers thereby signifying that the amount of photosynthates produced may have been higher in the treated plants in comparison to the uninoculated control plants, thereby, resulting in an increase in the above ground biomass of the rice plants. Increase in shoot dry mass has been reported in response to bacterial inoculation in maize (Gholami et al., 2009) and rice (Salamone et al., 2012).

Chlorophyll a content is an important parameter directly related to the amount of photosynthesis in the plants and hence in turn to the final production. In our investigation it was observed that the chlorophyll content was foundhigher in comparison to the untreated control plants in response to the bacterial treatment because inoculated bacteria improved the mineral nutrition, and in general, health of the plants thereby leading to an increase in the chlorophyll content. A linear relationship exists between 
concentration, in this regard Arif et al. (2012) reported an increase of $43 \%$ in chlorophyll content in response to
Zn fertilization; further PGPR application increased the chlorophyll content by almost 50\% (Bal et al., 2012).

Table 2. Effect of seedling treatment with different plant growth promoting rhizobacteria on root and shoot dry matter in three genotypes of rice 30 days after transplanting.

\begin{tabular}{|c|c|c|c|c|c|}
\hline \multirow[t]{2}{*}{ Genotypes } & \multirow[t]{2}{*}{ Treatments } & \multicolumn{2}{|c|}{ Root dry matter (g/plant) } & \multicolumn{2}{|c|}{ Shoot dry matter (g/plant) } \\
\hline & & 2010 & 2011 & 2010 & 2011 \\
\hline \multirow[t]{9}{*}{ Jaya } & P. putida & $3.55 \pm 0.77 \mathrm{abc}$ & $5.07 \pm 0.75 a-d$ & $8.88 \pm 1.83 \mathrm{ab}$ & $12.23 \pm 1.25 \mathrm{abc}$ \\
\hline & P. fluorescens & $3.15 \pm 0.64 \mathrm{abc}$ & $5.80 \pm 0.69 \mathrm{abc}$ & $9.47 \pm 1.22 \mathrm{ab}$ & $11.50 \pm 1.24 \mathrm{abc}$ \\
\hline & A. lipoferum & $3.26 \pm 0.33 \mathrm{abc}$ & $5.27 \pm 0.34 \mathrm{a}-\mathrm{d}$ & $8.13 \pm 1.72 \mathrm{ab}$ & $12.23 \pm 0.54 \mathrm{abc}$ \\
\hline & B 15 & $4.47 \pm 0.39 a$ & $5.83 \pm 0.40 \mathrm{abc}$ & $11.57 \pm 1.05 \mathrm{a}$ & $13.33 \pm 0.80 \mathrm{abc}$ \\
\hline & B 17 & $4.24 \pm 0.67 \mathrm{ab}$ & $5.03 \pm 0.55 \mathrm{a}-\mathrm{d}$ & $10.30 \pm 0.65 \mathrm{ab}$ & $13.67 \pm 0.71 \mathrm{abc}$ \\
\hline & B 19 & $3.72 \pm 0.53 \mathrm{abc}$ & $6.37 \pm 0.68 \mathrm{ab}$ & $10.27 \pm 0.65 \mathrm{ab}$ & $18.00 \pm 1.64 \mathrm{a}$ \\
\hline & BN 17 & $3.40 \pm 0.29 \mathrm{abc}$ & $3.80 \pm 0.43 \mathrm{~cd}$ & $10.03 \pm 0.68 \mathrm{ab}$ & $11.80 \pm 1.61 \mathrm{abc}$ \\
\hline & BN 30 & $3.02 \pm 0.55 \mathrm{abc}$ & $4.73 \pm 0.72 \mathrm{a}-\mathrm{d}$ & $10.03 \pm 118 \mathrm{ab}$ & $12.50 \pm 0.43 \mathrm{abc}$ \\
\hline & Control & $2.63 \pm 0.25 b c$ & $3.20 \pm 0.57 \mathrm{~d}$ & $7.73 \pm 0.55 b$ & $11.73 \pm 0.32 \mathrm{abc}$ \\
\hline \multirow[t]{9}{*}{ PA6444 } & P. putida & $3.68 \pm 0.78 \mathrm{abc}$ & $6.47 \pm 0.16 \mathrm{a}$ & $9.30 \pm 1.18 \mathrm{ab}$ & $14.57 \pm 0.97 \mathrm{abc}$ \\
\hline & P. fluorescens & $4.11 \pm 0.33 \mathrm{abc}$ & $4.83 \pm 0.57 \mathrm{a}-\mathrm{d}$ & $10.27 \pm 1.41 \mathrm{ab}$ & $13.37 \pm 0.82 \mathrm{abc}$ \\
\hline & A. lipoferum & $3.35 \pm 0.42 \mathrm{abc}$ & $5.67 \pm 0.35 \mathrm{abc}$ & $9.17 \pm 1.12 \mathrm{ab}$ & $11.67 \pm 1.09 \mathrm{abc}$ \\
\hline & В 15 & $3.08 \pm 0.64 \mathrm{abc}$ & $4.37 \pm 0.35 \mathrm{a}-\mathrm{d}$ & $9.53 \pm 1.27 \mathrm{ab}$ & $11.60 \pm 0.42 \mathrm{abc}$ \\
\hline & B 17 & $3.89 \pm 0.65 \mathrm{abc}$ & $5.73 \pm 0.32 \mathrm{abc}$ & $9.77 \pm 1.12 \mathrm{ab}$ & $17.20 \pm 0.83 \mathrm{ab}$ \\
\hline & В 19 & $4.12 \pm 0.31 \mathrm{abc}$ & $4.33 \pm 0.62 \mathrm{a}-\mathrm{d}$ & $11.07 \pm 0.58 \mathrm{ab}$ & $11.93 \pm 0.75 \mathrm{abc}$ \\
\hline & BN 17 & $3.29 \pm 0.92 \mathrm{abc}$ & $5.60 \pm 0.27 \mathrm{abc}$ & $9.97 \pm 0.67 \mathrm{ab}$ & $15.20 \pm 1.75 \mathrm{abc}$ \\
\hline & BN 30 & $3.71 \pm 0.15 \mathrm{abc}$ & $4.07 \pm 0.46 \mathrm{bcd}$ & $10.20 \pm 1.03 \mathrm{ab}$ & $9.87 \pm 0.16 \mathrm{c}$ \\
\hline & Control & $2.74 \pm 0.16 b c$ & $3.60 \pm 0.50 \mathrm{~cd}$ & $7.87 \pm 0.83 \mathrm{~b}$ & $9.80 \pm 0.23 \mathrm{c}$ \\
\hline Pusa & P. putida & $3.96 \pm 0.71 \mathrm{abc}$ & $5.27 \pm 1.41 \mathrm{a}-\mathrm{d}$ & $9.63 \pm 1.52 \mathrm{ab}$ & $10.50 \pm 1.49 b c$ \\
\hline \multirow{8}{*}{ Basmati-1 } & P. fluorescens & $2.84 \pm 0.12 b c$ & $4.37 \pm 0.86 \mathrm{a}-\mathrm{d}$ & $9.03 \pm 1.53 \mathrm{ab}$ & $15.33 \pm 1.49 \mathrm{abc}$ \\
\hline & A. lipoferum & $4.36 \pm 0.75 \mathrm{a}$ & $4.70 \pm 0.85 \mathrm{a}-\mathrm{d}$ & $10.10 \pm 1.22 \mathrm{ab}$ & $13.63 \pm 1.45 \mathrm{abc}$ \\
\hline & B 15 & $3.67 \pm 0.35 \mathrm{abc}$ & $5.20 \pm 0.60 \mathrm{a}-\mathrm{d}$ & $9.37 \pm 1.20 \mathrm{ab}$ & $13.30 \pm 1.75 \mathrm{abc}$ \\
\hline & B 17 & $3.29 \pm 0.63 \mathrm{abc}$ & $5.10 \pm 0.62 \mathrm{a}-\mathrm{d}$ & $11.87 \pm 0.52 \mathrm{a}$ & $14.37 \pm 1.35 \mathrm{abc}$ \\
\hline & B 19 & $4.16 \pm 0.32 \mathrm{abc}$ & $4.00 \pm 0.58 \mathrm{~cd}$ & $8.67 \pm 1.24 \mathrm{ab}$ & $10.67 \pm 1.05 b c$ \\
\hline & BN 17 & $3.74 \pm 0.70 \mathrm{abc}$ & $4.87 \pm 0.42 \mathrm{a}-\mathrm{d}$ & $9.17 \pm 0.58 \mathrm{ab}$ & $13.03 \pm 0.82 \mathrm{abc}$ \\
\hline & BN 30 & $3.96 \pm 0.31 \mathrm{abc}$ & $4.50 \pm 0.44 \mathrm{a}-\mathrm{d}$ & $9.87 \pm 1.07 \mathrm{ab}$ & $14.07 \pm 0.36 \mathrm{abc}$ \\
\hline & Control & $2.61 \pm 0.17 \mathrm{c}$ & $3.63 \pm 0.50 \mathrm{~cd}$ & $7.50 \pm 0.67 b$ & $10.30 \pm 0.15 b c$ \\
\hline
\end{tabular}

Means followed by a common letter in the columns are not significantly different.

Iron and zinc content of roots is defined by the soil conditions, fertilization and activity of the roots and related micro organisms. We observed an increase in root iron and zinc content in response to the bacterial inoculation. The increased root uptake and accumulation of micronutrients was due to the increased root activity and also the solubilization of iron and zinc compounds present in the soil. In similar experiments Mishra et al.
(2011) has reported an increase in Fe and $\mathrm{Zn}$ content in lentil. In rice, Purakayastha and Chhonkar (2001) has shown similar results in response to mycorrhizal fungi. Besides increasing the $\mathrm{Fe}$ and $\mathrm{Zn}$ content in roots bacterial inoculation also improved the root activity thereby leading to an increase in the translocation of $\mathrm{Fe}$ and $\mathrm{Zn}$ from root to shoots, as a result shoot $\mathrm{Fe}$ and $\mathrm{Zn}$ content was also found to be increased. 
In experiments based on similar approach Rana et al. (2012) reported an increase in Fe and $\mathrm{Zn}$ content of wheat shoots and Shabayev (2012) has reported an increase of around $30 \%$ in $\mathrm{Fe}$ and $41 \%$ in $\mathrm{Zn}$ in wheat in response to PGPR treatment; we have also reported an increase in the root and shoot Fe content in rice in response to PGPR treatment (Sharma et al., 2013).

Grain number defines the amount of yield that can be obtained from any crop plant. Higher grain number results from increased translocation of photosynthates from the leaves to the developing spikelets. Hence, increase in grain number signifies an increased amount of photosynthesis which leads to disturbance of source-sink ratio shifting it towards sink, resulting in increased translocation of photosynthates from leaves to the grains thereby resulting in an increased number of grains per panicle and ultimately increased yield. However, this increase in grain yield might also be due to the high $\mathrm{Zn}$ solubilization potential of these isolates. All isolates viz. B 15 through $\mathrm{BN} 30$ are strong $\mathrm{Zn}$ solubilizers, hence the assumption that increase in the $\mathrm{Zn}$ uptake by the plant results in a greater yield holds true. As was observed in our study, a large body of evidence shows that PGPR enhance the growth, seed emergence and crop yield, and contribute to the nutrient enrichment of plants (Dey et al., 2004; Kloepper et al., 2004; Herman et al., 2008; Minorsky, 2008). Salamone et al. (2012) reported that PGPR inoculation reduced the chaffy grain percentage in rice plants; a $10 \%$ increase in grain number in wheat in response to PGPR treatment was reported by Rana et al. (2012); also higher number of grains in lentil plants were reported by Zafar et al. (2012) in response to bacterial inoculation; in another experiment increased grain number was reported in cowpea plants in response to PGPR treatment by Minaxi et al. (2012).

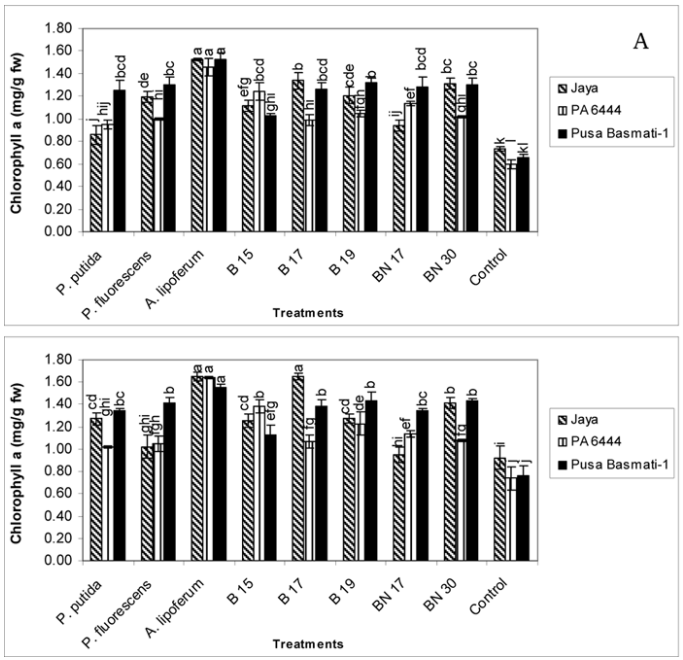

Figure 1. Chlorophyll a content ( $\left.\mathrm{mg} \mathrm{g}^{-1} \mathrm{FW}\right)$ of three rice genotypes under different bacterial treatments 30 days after translating during the planting seasons 2010 (A) and 2011 (B). Means followed by a common letter in the columns are not significantly different.

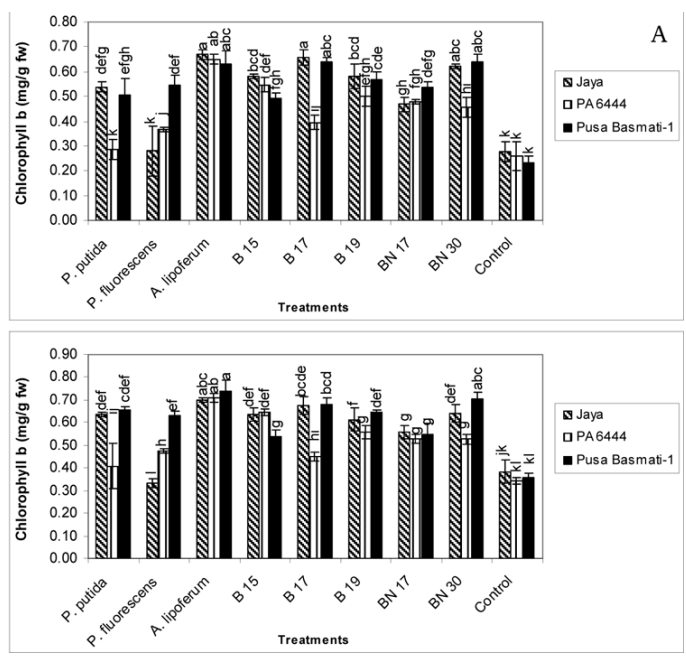

Figure 2. Chlorophyll $\mathrm{b}$ content $\left(\mathrm{mg} \mathrm{g}^{-1} \mathrm{FW}\right)$ of three rice genotypes under different bacterial treatments 30 days after transplanting during the planting seasons 2010 (A) and 2011 (B). Means followed by a common letter in the columns are not significantly different. 
Table 3a. Effect of seedling treatment with different plant growth promoting rhizobacteria on zinc and iron content in root and shoot portions of three genotypes of rice 30 days after transplanting.

\begin{tabular}{|c|c|c|c|c|c|}
\hline \multirow[t]{2}{*}{ Genotypes } & \multirow[t]{2}{*}{ Treatments } & \multicolumn{2}{|c|}{ Root zinc content } & \multicolumn{2}{|c|}{ Shoot zinc content } \\
\hline & & 2010 & 2011 & 2010 & 2011 \\
\hline \multirow[t]{9}{*}{ Jaya } & P. putida & $5.97 \pm 0.58 \mathrm{c}-f$ & $14.70 \pm 1.50 \mathrm{bcd}$ & $13.0 \pm 2.59 \mathrm{e}$ & $19.3 \pm 1.72 \mathrm{a}-\mathrm{e}$ \\
\hline & P. fluorescens & $8.10 \pm 1.05 \mathrm{ab}$ & $12.98 \pm 1.81 \mathrm{bcd}$ & $14.7 \pm 2.10 \mathrm{de}$ & $19.7 \pm 2.11 \mathrm{a}-\mathrm{e}$ \\
\hline & A. lipoferum & $7.75 \pm 0.87 \mathrm{a}-\mathrm{d}$ & $11.03 \pm 0.83 \mathrm{bcd}$ & $15.5 \pm 1.99 \mathrm{cde}$ & $17.2 \pm 0.57 \mathrm{a}-\mathrm{e}$ \\
\hline & B 15 & $7.23 \pm 0.32 \mathrm{a}-\mathrm{e}$ & $15.50 \pm 1.12 \mathrm{bcd}$ & $18.4 \pm 2.55 \mathrm{a}-\mathrm{e}$ & $18.7 \pm 1.15 \mathrm{a}-\mathrm{e}$ \\
\hline & B 17 & $6.97 \pm 0.96 \mathrm{a}-\mathrm{f}$ & $9.78 \pm 1.79 \mathrm{bcd}$ & $22.6 \pm 1.03 \mathrm{a}-\mathrm{e}$ & $28.5 \pm 143 \mathrm{ab}$ \\
\hline & В 19 & $6.42 \pm 0.50 \mathrm{~b}-\mathrm{f}$ & $10.30 \pm 0.57 \mathrm{bcd}$ & $18.1 \pm 0.97 \mathrm{a}-\mathrm{e}$ & $21.1 \pm 2.42 \mathrm{a}-\mathrm{e}$ \\
\hline & BN 17 & $7.45 \pm 0.87 \mathrm{a}-\mathrm{e}$ & $9.57 \pm 0.72 \mathrm{bcd}$ & $18.9 \pm 1.01 \mathrm{a}-\mathrm{e}$ & $21.6 \pm 3.44 \mathrm{a}-\mathrm{e}$ \\
\hline & BN 30 & $5.72 \pm 0.67 \mathrm{ef}$ & $12.10 \pm 1.43 \mathrm{bcd}$ & $20.4 \pm 1.22 \mathrm{a}-\mathrm{e}$ & $20.0 \pm 1.98 \mathrm{a}-\mathrm{e}$ \\
\hline & Control & $5.12 \pm 0.47 \mathrm{f}$ & $8.07 \pm 1.13 \mathrm{bcd}$ & $12.4 \pm 0.97 \mathrm{e}$ & $10.6 \pm 0.83 \mathrm{de}$ \\
\hline \multirow[t]{9}{*}{ PA6444 } & P. putida & $8.67 \pm 0.83 \mathrm{a}$ & $15.95 \pm 1.81 \mathrm{bc}$ & $17.5 \pm 2.60 \mathrm{a}-\mathrm{e}$ & $22.4 \pm 0.38 \mathrm{a}-\mathrm{e}$ \\
\hline & P. fluorescens & $7.13 \pm 1.05 \mathrm{a}-\mathrm{e}$ & $11.82 \pm 1.63 \mathrm{bcd}$ & $12.6 \pm 0.99 \mathrm{e}$ & $19.0 \pm 2.23 \mathrm{a}-\mathrm{e}$ \\
\hline & A. lipoferum & $7.37 \pm 0.88 \mathrm{a}-\mathrm{e}$ & $10.38 \pm 0.61 \mathrm{bcd}$ & $14.7 \pm 1.76 \mathrm{de}$ & $19.0 \pm 1.51 \mathrm{a}-\mathrm{e}$ \\
\hline & В 15 & $6.32 \pm 0.94 b-f$ & $11.90 \pm 1.71 \mathrm{bcd}$ & $13.9 \pm 2.22 \mathrm{e}$ & $17.3 \pm 1.59 \mathrm{a}-\mathrm{e}$ \\
\hline & B 17 & $6.05 \pm 0.44 c-f$ & $11.37 \pm 0.84 \mathrm{bcd}$ & $26.5 \pm 1.94 \mathrm{ab}$ & $25.8 \pm 2.15 \mathrm{a}-\mathrm{e}$ \\
\hline & В 19 & $7.20 \pm 0.64 \mathrm{a}-\mathrm{e}$ & $9.32 \pm 1.32 \mathrm{bcd}$ & $19.4 \pm 1.75 \mathrm{a}-\mathrm{e}$ & $17.8 \pm 1.75 \mathrm{a}-\mathrm{e}$ \\
\hline & BN 17 & $7.45 \pm 0.75$ a-e & $26.67 \pm 0.61 \mathrm{a}$ & $21.3 \pm 2.91$ a-e & $11.6 \pm 0.48 \mathrm{~b}-\mathrm{e}$ \\
\hline & $\mathrm{BN} 30$ & $6.28 \pm 0.65 b-f$ & $8.28 \pm 1.15 \mathrm{bcd}$ & $24.9 \pm 2.21 \mathrm{a}-\mathrm{d}$ & $11.8 \pm 1.65 b-e$ \\
\hline & Control & $5.48 \pm 0.38 \mathrm{ef}$ & $6.82 \pm 0.57 \mathrm{~cd}$ & $12.8 \pm 0.96 \mathrm{e}$ & $10.1 \pm 0.95 \mathrm{e}$ \\
\hline Pusa & P. putida & $7.13 \pm 1.05 \mathrm{a}-\mathrm{e}$ & $17.02 \pm 1.54 b$ & $19.1 \pm 2.87 \mathrm{a}$-e & $28.3 \pm 1.43 \mathrm{abc}$ \\
\hline \multirow[t]{8}{*}{ Basmati-1 } & P. fluorescens & $6.20 \pm 0.57 b-f$ & $12.98 \pm 1.75 \mathrm{bcd}$ & $17.2 \pm 1.15 \mathrm{a}-\mathrm{e}$ & $16.6 \pm 1.07 \mathrm{a}-\mathrm{e}$ \\
\hline & A. lipoferum & $7.07 \pm 0.78 \mathrm{a}-\mathrm{f}$ & $9.55 \pm 1.04 \mathrm{bcd}$ & $17.8 \pm 1.09 \mathrm{a}-\mathrm{e}$ & $24.0 \pm 2.05 \mathrm{a}-\mathrm{e}$ \\
\hline & B 15 & $6.23 \pm 0.64 b-f$ & $14.15 \pm 1.40 \mathrm{bcd}$ & $12.5 \pm 1.17 \mathrm{e}$ & $14.4 \pm 1.10 \mathrm{a}-\mathrm{e}$ \\
\hline & B 17 & $6.38 \pm 0.07 b-f$ & $8.30 \pm 0.98$ bed & $26.7 \pm 1.91 \mathrm{a}$ & $29.6 \pm 2.33 a$ \\
\hline & В 19 & $6.52 \pm 0.55 b-f$ & $14.13 \pm 0.54 \mathrm{bcd}$ & $17.3 \pm 2.76 \mathrm{a}-\mathrm{e}$ & $27.4 \pm 2.15 \mathrm{a}-\mathrm{d}$ \\
\hline & BN 17 & $5.98 \pm 0.91 \mathrm{c}-\mathrm{f}$ & $10.15 \pm 0.66 \mathrm{bcd}$ & $16.2 \pm 2.19 \mathrm{~b}-\mathrm{e}$ & $13.7 \pm 1.13 \mathrm{a}-\mathrm{e}$ \\
\hline & BN 30 & $7.93 \pm 0.27 \mathrm{abc}$ & $10.80 \pm 0.85 \mathrm{bcd}$ & $25.4 \pm 1.96 \mathrm{abc}$ & $12.0 \pm 0.97 \mathrm{~b}-\mathrm{e}$ \\
\hline & Control & $5.83 \pm 0.98 \mathrm{def}$ & $6.20 \pm 0.72 \mathrm{~cd}$ & $16.8 \pm 1.09 \mathrm{a}-\mathrm{e}$ & $11.2 \pm 0.75 \mathrm{cde}$ \\
\hline
\end{tabular}

Means followed by a common letter in the columns are not significantly different. 
Table 3b. Effect of seedling treatment with different plant growth promoting rhizobacteria on zinc and iron content in root and shoot portions of three genotypes of rice 30 days after transplanting.

\begin{tabular}{|c|c|c|c|c|c|}
\hline \multirow[t]{2}{*}{ Genotypes } & \multirow[t]{2}{*}{ Treatments } & \multicolumn{2}{|c|}{ Root iron content } & \multicolumn{2}{|c|}{ Shoot iron content } \\
\hline & & 2010 & 2011 & 2010 & 2011 \\
\hline \multirow[t]{9}{*}{ Jaya } & P. putida & $454.6 \pm 7.73 \mathrm{a}$ & $448.6 \pm 10.9 \mathrm{a}$ & $154.2 \pm 16.7 \mathrm{def}$ & $201.5 \pm 30.8 \mathrm{abc}$ \\
\hline & P. fluorescens & $397.2 \pm 11.9 \mathrm{a}-\mathrm{f}$ & $444.2 \pm 16.3 \mathrm{a}$ & $142.4 \pm 10.1 \mathrm{e}-\mathrm{h}$ & $183.7 \pm 22.6 \mathrm{bcc}$ \\
\hline & A. lipoferum & $409.2 \pm 29.6 \mathrm{a}-\mathrm{e}$ & $425.4 \pm 18.5 \mathrm{ab}$ & $134.3 \pm 12.2 \mathrm{e}-\mathrm{i}$ & $172.9 \pm 13.1 b-\mathrm{e}$ \\
\hline & B 15 & $357.8 \pm 27.5 \mathrm{c}-\mathrm{h}$ & $384.0 \pm 21.3 \mathrm{abc}$ & $145.2 \pm 19.5 \mathrm{~d}-\mathrm{h}$ & $107.4 \pm 16.1 \mathrm{de}$ \\
\hline & B 17 & $366.8 \pm 27.1 b-h$ & $463.3 \pm 18.1 \mathrm{a}$ & $203.9 \pm 17.9 b c$ & $245.4 \pm 13.5 \mathrm{a}$ \\
\hline & B 19 & $304.1 \pm 26.1 \mathrm{gh}$ & $386.9 \pm 18.3 \mathrm{abc}$ & $222.2 \pm 9.77 \mathrm{ab}$ & $234.1 \pm 18.3 \mathrm{ab}$ \\
\hline & $\mathrm{BN} 17$ & $303.0 \pm 15.8 \mathrm{gh}$ & $419.5 \pm 21.6 \mathrm{ab}$ & $123.0 \pm 16.6 f-i$ & $138.6 \pm 15.1 b-e$ \\
\hline & $\mathrm{BN} 30$ & $356.3 \pm 21.2 \mathrm{c}-\mathrm{h}$ & $412.5 \pm 22.1 \mathrm{ab}$ & $206.2 \pm 14.2 b c$ & $238.4 \pm 13.6 \mathrm{ab}$ \\
\hline & Control & $290.8 \pm 14.2 \mathrm{~h}$ & $335.3 \pm 15.8 \mathrm{~cd}$ & $102.2 \pm 3.50 \mathrm{i}$ & $97.4 \pm 10.1 \mathrm{e}$ \\
\hline \multirow[t]{9}{*}{ PA6444 } & P. putida & $455.1 \pm 7.46 \mathrm{a}$ & $461.5 \pm 13.3 \mathrm{a}$ & $199.1 \pm 28.4 b c$ & $200.1 \pm 24.1 \mathrm{abc}$ \\
\hline & P. fluorescens & $452.4 \pm 10.2 \mathrm{ab}$ & $446.8 \pm 4.66 \mathrm{a}$ & $245.2 \pm 24.9 \mathrm{a}$ & $240.9 \pm 24.4 \mathrm{a}$ \\
\hline & A. lipoferum & $380.1 \pm 21.5 \mathrm{a}-\mathrm{g}$ & $449.8 \pm 15.1 \mathrm{a}$ & $146.6 \pm 9.95 \mathrm{~d}-\mathrm{h}$ & $182.3 \pm 15.2 b-e$ \\
\hline & B 15 & $384.3 \pm 12.3 \mathrm{a}-\mathrm{g}$ & $382.7 \pm 17.8 \mathrm{abc}$ & $158.1 \pm 15.9 \mathrm{def}$ & $145.1 \pm 18.6 b-c$ \\
\hline & B 17 & $343.2 \pm 30.6 \mathrm{~d}-\mathrm{h}$ & $454.4 \pm 12.6 \mathrm{a}$ & $140.0 \pm 10.5 \mathrm{e}-\mathrm{h}$ & $169.9 \pm 14.6 \mathrm{~b}-\mathrm{e}$ \\
\hline & В 19 & $287.9 \pm 33.0 \mathrm{~h}$ & $401.4 \pm 26.4 \mathrm{abc}$ & $133.1 \pm 11.3 \mathrm{e}-\mathrm{i}$ & $148.6 \pm 13.5 b-e$ \\
\hline & BN 17 & $287.7 \pm 23.5 \mathrm{~h}$ & $411.5 \pm 18.3 \mathrm{abc}$ & $147.3 \pm 19.6 \mathrm{~d}-\mathrm{g}$ & $149.9 \pm 13.9 b-e$ \\
\hline & $\mathrm{BN} 30$ & $314.8 \pm 26.8 \mathrm{fgh}$ & $431.2 \pm 12.2 \mathrm{ab}$ & $133.6 \pm 8.49 \mathrm{e}-\mathrm{i}$ & $157.0 \pm 19.4 b-e$ \\
\hline & Control & $304.9 \pm 22.4 \mathrm{gh}$ & $357.2 \pm 21.4 \mathrm{bcd}$ & $114.5 \pm 9.86 \mathrm{ghi}$ & $121.6 \pm 11.5 \mathrm{cde}$ \\
\hline Pusa & P. putida & $421.9 \pm 23.9 \mathrm{a}-\mathrm{d}$ & $434.9 \pm 16.0 \mathrm{ab}$ & $166.0 \pm 13.6 \mathrm{de}$ & $209.6 \pm 21.5 \mathrm{abc}$ \\
\hline \multirow[t]{8}{*}{ Basmati-1 } & P. fluorescens & $435.9 \pm 10.3 \mathrm{abc}$ & $454.0 \pm 9.07 \mathrm{a}$ & $179.5 \pm 29.3 \mathrm{~cd}$ & $158.9 \pm 24.2 b-c$ \\
\hline & A. lipoferum & $327.8 \pm 30.4 \mathrm{e}-\mathrm{h}$ & $400.0 \pm 11.8 \mathrm{abc}$ & $139.0 \pm 10.2 \mathrm{e}-\mathrm{h}$ & $125.7 \pm 14.6 \mathrm{cde}$ \\
\hline & B 15 & $399.0 \pm 13.8 \mathrm{a}-\mathrm{f}$ & $396.1 \pm 18.9 \mathrm{abc}$ & $155.0 \pm 13.4 \mathrm{def}$ & $130.8 \pm 22.0 \mathrm{cde}$ \\
\hline & B 17 & $311.9 \pm 24.3 \mathrm{fgh}$ & $435.8 \pm 11.2 \mathrm{ab}$ & $135.3 \pm 10.2 \mathrm{e}-\mathrm{i}$ & $106.8 \pm 20.8 \mathrm{de}$ \\
\hline & B 19 & $357.6 \pm 29.8 c-h$ & $451.0 \pm 13.5 \mathrm{a}$ & $154.4 \pm 14.2 \mathrm{def}$ & $145.9 \pm 12.2 b-e$ \\
\hline & BN 17 & $303.6 \pm 21.5 \mathrm{gh}$ & $427.3 \pm 21.5 \mathrm{ab}$ & $111.3 \pm 11.4 \mathrm{hi}$ & $134.2 \pm 18.2 \mathrm{cde}$ \\
\hline & $\mathrm{BN} 30$ & $305.0 \pm 28.1 \mathrm{gh}$ & $422.4 \pm 25.8 \mathrm{ab}$ & $127.8 \pm 7.38 \mathrm{f}-\mathrm{i}$ & $135.7 \pm 16.5 b-e$ \\
\hline & Control & $289.9 \pm 12.8 \mathrm{~h}$ & $302.8 \pm 23.1 \mathrm{~d}$ & $113.0 \pm 10.5 \mathrm{ghi}$ & $107.2 \pm 9.51 \mathrm{de}$ \\
\hline
\end{tabular}

Means followed by a common letter in the columns are not significantly different. 


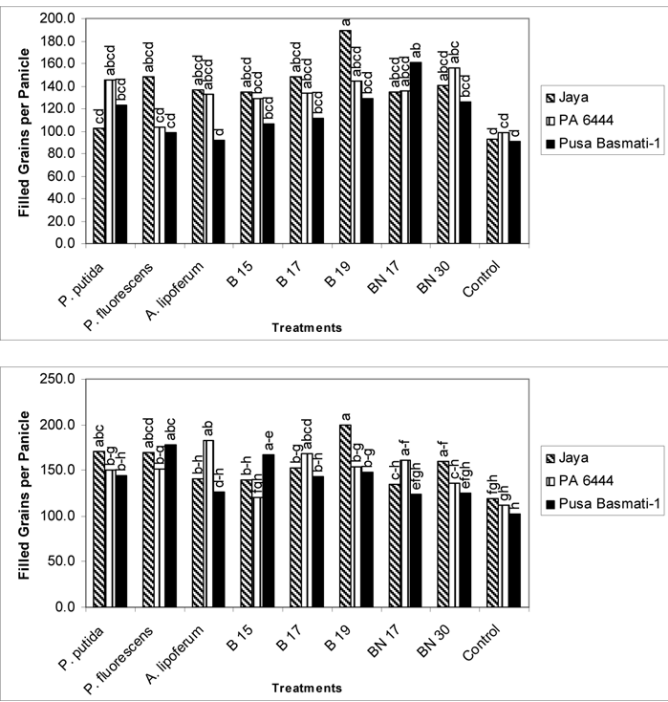

Figure 3. Filled grains per panicle of three rice genotypes under different bacterial treatments at harvesting during the planting seasons 2010 (A) and 2011 (B). Means followed by a common letter in the columns are not significantly different.
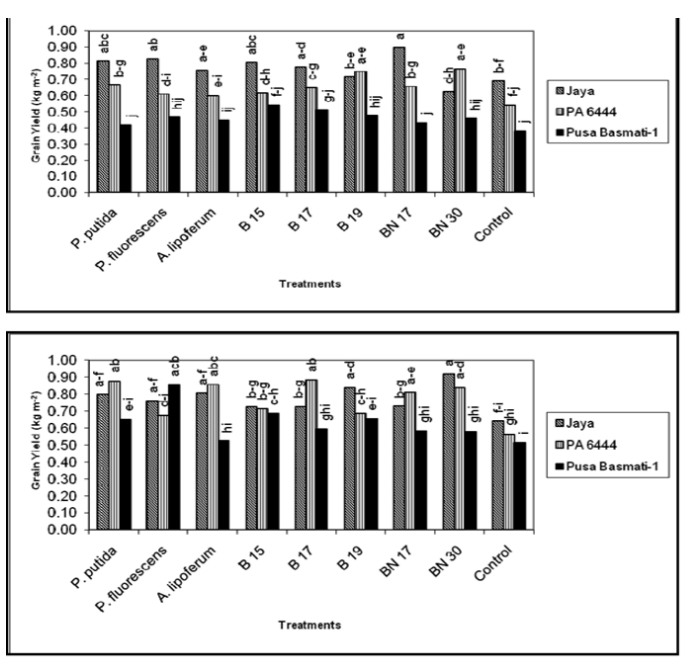

Figure 4. Grain Yield of three rice genotypes under different bacterial treatments at harvesting during the planting seasons 2010 (A) and 2011 (B). Means followed by a common letter in the columns are not significantly different.

\section{Conclusion}

The application of plant growth promoting rhizobacteria resulted in improving the vegetative growth of the rice plants and also helped in increasing the dry matter accumulation of the plants. Besides, improving growth of the plants, inoculation with PGPR also resulted in improving the zinc and iron status of the rice genotypes and an overall increase in the yield of the rice genotypes was observed. Hence it can be concluded that the application of PGPRs in rice not only improve the health of the plant but also increase the vegetative growth, photosynthetic capacity and micronutrient status of the crop. Therefore, judicious application of plant growth promoting rhizobacteria to rice holds immense potential that is still to be explored and it can also provide an answer to the global demand for the development of a sustainable strategy for biofortification.

\section{Acknowledgement}

The financial assistance received from CSIR, New Delhi, India during the period of this study is duly acknowledged.

\section{References}

Arif, M., Shehzad, M.A., Bashir, F., Tasneem, M., Yasin, G., Iqbal, M. 2012. Boron, zinc and microtone effects on growth, chlorophyll contents and yield attributes in rice (Oryza sativa L.) cultivar. Afr. J. Biotechnol. 11, 10851-10858.

Ashrafuzzaman, M., Hossen, F.A., Ismail, M.R., Hoque, M.A., Islam, M.Z., Shahidullah, S. M., Meon, S. 2009. Efficiency of plant growth promoting rhizobacteria (PGPR) for the enhancement of rice growth. Afr. J. Biotechnol. 8, 1247-1252. 
Bal, H.B., Nayak, L., Das, S., Adhya, T.K. 2012. Isolation of ACC deaminase producing PGPR from rice rhizosphere and evaluating their plant growth promoting activity under salt stress. Plant Soil. DOI 10.1007/s11104-012-1402-5

Baldani, V.L.D., Baldani, J.I., Dobereiner, J. 2000. Inoculation of rice plants with the endophytic diazotrophs Herbaspirillum seropedicae and Burkholderia spp. Biol. Fertility Soils. 30, 485491.

Bunt, J.S., Rovira, A.D. 1955. Microbiological studies of some subantartic soils. J. Soil Sci. 6, 119-128.

Gholami, A., Shahsavani, S., Nezarat, S. 2009. The effect of plant growth promoting rhizobacteria (PGPR) on germination, seedling growth and yield of maize. World Acad. Sci. Engg. \& Technol. 49, 19-24.

Glick, B.R., Cheng, Z., Czarny, J., Duan, J. 2007. Promotion of plant growth by ACC deaminaseproducing soil bacteria. Eur. J. Plant Pathol. 119, 329-339.

Herman, M.A.B., Nault, B.A., Smart, C.D. 2008 Effects of plant growth promoting rhizobacteria on bell pepper production and green peach aphid infestations in New York. Crop Protect. 27, 9961002.

Hiscox, J.D., Israelstam, G.F. 1979. A method for extraction of chlorophyll from leaf tissues without maceration. Can. J. Bot. 57, 1332-1334.

James, E.K., Gyaneshwar, P., Barraquio, W.L., Mathan, N., Ladha, J.K. 2000. Endophytic diazotrophs associated with rice. In: The Quest for Nitrogen Fixation in Rice. Ladha, J.K. and Reddy, P.M., eds. International Rice Research Institute, Los Baños, Philippines, pp. 119-140.
Kloepper, J.W., Ryu, C.M., Zhang, S. 2004. Induced systemic resistance and promotion of plant growth by Bacillus spp. Phytopathology. 94, 1259-1266.

Kuiper, I., Bloemberg, G.V., Lugtenberg, B.J.J. 2001. Selection of a plant-bacterium pair as a novel tool for rhizostimulation of polycyclic aromatic hydrocarbon-degrading bacteria. Mol. Plant Microbe Interact. 14, 1197-1205.

Kumar, K.V.K., Yellareddygari, S.K., Reddy, M.S., Kloepper, J.W., Lawrence, K.S., Zhou, X.G., Sudini, H., Groth, D.E., Raju, S.K., Miller, M.E. 2012. Efficacy of Bacillus subtilis MBI 600 against sheath blight caused by Rhizoctonia solani and on growth and yield of rice. Rice Science. 19, 55-63.

Lugtenberg, B., Kamilova, F. 2009. Plant Growth Promoting Rhizobacteria. Annu. Rev. Microbiol. 63, 541-56.

Minaxi, Nain, L.,Yadav, R.C., Saxena, J. 2012. Characterization of multifaceted Bacillus sp. RM-2 for its use as plant growth promoting bioinoculant for crops grown in semi arid deserts. App. Soil Ecol. 59, 124-135.

Minorsky, P.V. 2008. On the inside. Plant Physiol.146, 323-324.

Mishra, P.K., Bisht, S.C., Ruwari, P., Joshi, G.K., Singh, G., Bisht, J.K., Bhatt, J.C. 2011. Bioassociative effect of cold tolerant Pseudomonas spp. and Rhizobium leguminosarum-PR1 on iron acquisition, nutrient uptake and growth of lentil (Lens culinaris L.). Europ. J. Soil Biol. 47, 35-43.

Okon, Y., Bloemberg, G.V., Lugtenberg, B.J.J. 1998. Biotechnology of biofertilization and phytostimulation. In Agricultural Biotechnology, ed. A Altman, pp. 327-49. New York: Marcel Dekker 
Pirzadeh, M., Afyuni, M., Khoshgoftarmanesh, A., Schulin, R. 2010. Micronutrient status of calcareous paddy soils and rice products: Implication for human health. Biol. Fertil. Soils. 46, 317-322.

Purakayastha, T.J., Chhonkar, P. K. 2001. Influence of vesicular-arbuscular mycorrhizal fungi (Glomus etunicatum L.) on mobilization of zinc in wetland rice (Oryza sativa L). Biol. Fertil. Soils. 33, 323327.

Rana, A., Joshi, M., Prasanna, R., Shivay, Y.S., Nain, L. 2012. Biofortification of wheat through inoculation of plant growth promoting rhizobacteria and cyanobacteria. Europ. J. Soil Biol. 50, 118-126.

Salamone, I.E.G., Funes, J.M., Salvo, L.P., Ortega, J.E.S., D'Auria, F., Ferrando, L., Scavino, A.F. 2012. Inoculation of paddy rice with Azospirillum brasilense and Pseudomonas fluorescens: Impact of plant genotypes on rhizosphere microbial communities and field crop production. App. Soil Ecol. 61, 196- 204.

Schwyn, B., Neilands, J.B. 1987. Universal chemical assay for the detection and determination of siderophores. Anal. Biochem. 160, 47-56.

Shabayev, V.P. 2012. Mineral Nutrition of plants inoculated with plant growth promoting rhizobacteria of Pseudomonas genus. Biol Bulletin Rev. 2, 487-499.

Sharma, A., Shankhdhar, D., Shankhdhar, S.C. 2013. Enhancing grain iron content of rice by the applicationof plant growth promoting rhizobacteria. Plant Soil Environ. 59, 89-94.
Souza, R., Beneduzi, A., Ambrosini, A., Costa, P.B., Meyer, J., Vargas, L. K., Schoenfeld, R., Passaglia, L. M.P. 2012. The effect of plant growth-promoting rhizobacteria on the growth of rice (Oryza sativa L.) cropped in southern Brazilian fields. Plant Soil. DOI 10.1007/s11104-012-1430-1

Souza, R., Beneduzi, A., Ambrosini, A., Costa, P.B., Meyer, J., Vargas, L. K., Schoenfeld, R., Passaglia, L. M. P. 2012. The effect of plant growth-promoting rhizobacteria on the growth of rice (Oryza sativa L.) cropped in southern Brazilian fields. Plant Soil. DOI 10.1007/s11104-012-1430-1

Van Rijhn, P., Vanderleyden, J. 1995. The Rhizobiumplant symbiosis. Microbiol. Rev. 59, 124-142.

Vassilev, N., Vassileva, M., Nicolaeva, I. 2006. Simultaneous P-solubilizing and biocontrol activity of microorganisms: potentials and future trends. Appl. Microbiol. Biotechnol. 71, 137-144.

Yanni, Y.G., El-Fattah, F.K.A. 1999. Towards integrated biofertilization management with free living and associative dinitrogen fixers for enhancing rice performance in the Nile delta. Symbiosis. 27, 319-331.

Zafar, M., Abbasi, M.K., Khan, M.A., Khaliq, A., Sultan, T., Aslam, M. 2012. Effect of plant growthpromoting rhizobacteria on growth, nodulation and nutrient accumulation of lentil under controlled conditions. Pedosphere. 22, 848-859. 